\title{
AQ:4 The role of omnichannel tendency in digital information processing
}

\author{
Paula Rodríguez-Torrico and Sonia San-Martín \\ Economics and Business Administration,
}

Facultad de Ciencias Economicas y Empresariales, Universidad de Burgos, Burgos, Spain, and

\begin{abstract}
Purpose - Nowadays some consumers consider themselves as "omnichannels" - they combine both physical and digital channels expecting a seamless shopping experience - since they view their shopping process from a multiple-channel viewpoint. Giving that situation, the aim of this paper is to test the role of consumers' omnichannel tendency (omni-tendency) in the information processing in the digital channel.

Design/methodology/approach - Based on the Elaboration Likelihood Model (ELM), emotions as well as utilitarian and hedonic experiences are proposed to understand consumer attitude towards the digital store. Through a survey, data were collected from 284 digital shoppers. PLS path modelling and PLS-MGA were used to test the research hypotheses.

Findings - The results confirm that emotions positively affect the evaluation of the experiences, which in turn improves the attitude towards the digital store. Focusing on the differences among consumers, the findings show that for consumers with low omni-tendency the emotions are key to improve the evaluation of their experiences. Moreover, regarding the attitude, consumers with more omni-tendency follow the central route to process the information; and consumers with less omni-tendency follow the peripheral route.

Originality/value - This paper contributes to the literature in three ways. First, this research includes the study of omni-tendency, as a consumer trait, in the information processing developed in the digital channel, ignored in the literature. Second, this work contributes to information processing theories in digital context confirming, specifically the applicability of ELM into the omnichannel context. This offers support to the application of traditional theories to explain new phenomena. Third, and in line with the previous contribution, this work goes a step further in understanding ELM theory by including other constructs -the omni-tendency and emotions- to explain the information processing in the digital context.
\end{abstract}

Keywords Omnichannel tendency, Emotions, Experiences, Digital channel, Information processing Paper type Research paper

\section{Introduction}

In this "always-on" and "multidevice" era, consumers are evolving in the way they interact with the company. The growing number of touchpoints and devices increases consumers' expectations about their use, who assume that they can combine them when shopping (Piotrowicz and Cuthbertson, 2014; Shen et al., 2018; Verhoef et al., 2015). As a result, some consumers have become omnichannel. But this change has developed gradually until now. The omnichannel consumer is an evolution of the multichannel consumer, whose behaviour has changed from using few channels in parallel to using all touchpoints simultaneously (Lazaris and Vrechopoulos, 2014). Specifically, in multichannel retailing, the channels are managed separately within firms, with limited integration between them (Verhoef et al., 2015). However, in omnichannel retailing, there is a broad number of channels that are fully integrated and interconnected (Shen $\mathrm{et}$ al., 2018; Verhoef et al., 2015).

Following the omnichannel behaviour definition, omnichannel consumers (omnichannels or omni-consumers) are those who use both physical and digital channels combined with the delivery of seamless shopping experiences (Lazaris and Vrechopoulos, 2014). This behaviour is becoming increasingly common among consumers and crucial for firms; $73 \%$ of consumers
Omnichannel in digital information processing 
use multiple channels during their shopping journey; and these consumers are more valuable, since they spend an average of $4-10 \%$ more on every shopping occasion than single-channel consumers (Sopadjieva et al., 2017).

However, this behaviour, and consequently, the tendency to behave in an omnichannel way, is not the same for all individuals. Literature has argued that as consumer level of experience with a technology increases, consumers are expected to have more ability to use the technology, which can be considered as a consumer personal characteristic (Yang, 2012). In this sense, the differences between consumers related to their individual traits are "at the heart of consumer attitude formation and behavioural intentions" (Dabholkar and Bagozzi, 2002, p. 187). Therefore, consumer experience engaging in omnichannel shopping can be turned into a technological-related trait - or consumers omnichannel tendency (omnitendency)-, that will affect their decision-making behaviour.

While marketing literature addressing channel combination has undergone substantial growth in recent years, there is still much to be learnt about consumers in the omnichannel context [1] (Ailawadi and Farris, 2017). In this sense, Dholakia et al. (2010) posit an approach for studying consumer behaviour in omnichannel environments. These authors argue that the new context embraces different consumers who have different reactions for different channels. Nevertheless, despite some researchers have pointed out that omni-consumers have different perceptions about the different channels (Ailawadi and Farris, 2017; Shen et al., 2018), to the best of our knowledge, no research has considered the impact of omniconsumers' particularities on their reactions for the different channels.

In order to fill this gap and analyse this situation, this paper focuses on the information processing in the digital channel [2]. In this sense, the Elaboration Likelihood Model (ELM) (Petty et al., 1983) that has been applied to understand the information processing in traditional channels (Trampe et al., 2010), and in digital contexts (Aghakhani et al., 2018; Cho, 1999), is extended in this particular case considering the omnichannel environment. Precisely, the motivation to process the information is described by consumers' emotions; the information processing is represented by the evaluation of the utilitarian and hedonic experiences; and, the consumer ability to process is the consumer omni-tendency. This proposal includes consumers' emotions and evaluations as independent variables following the idea that both affect and cognition are crucial for understanding human behaviour (Burke and Edell, 1989). However, the emotions are proposed as antecedents of evaluations following the biological theory of emotions (Zajonc, 1984). Following this theory, emotional states could be activated subconsciously as a result of the elements presented on the environment, which, in turn, will influence consumers' evaluation of the shopping experience.

In this manner, the ELM allows us to understand how the information processing that explains the attitude formation in the digital store can be influenced by this new omnitendency. In this sense, consumers' attitude has been confirmed as a prominent determinant of the intention of use and actual use (Oliveira et al., 2017; Xu-Priour et al., 2017). Accordingly, the influence of the new omnichannel behaviour on attitude towards the digital store is critical for businesses to manage the digital channel in an effective way. Therefore, the aim of this paper is to understand the influence of the individual omni-tendency on the information processing that explains attitude formation towards the digital store.

\section{Theoretical foundation and hypotheses development \\ 2.1 Elaboration Likelihood Model and its application to digital contexts}

Within information processing theories, ELM has been one of the most used approaches in literature (Kitchen et al., 2014). After the development of the ELM (Petty and Cacioppo, 1979), Petty et al. (1983) extended the use of this theory to analyse consumer behaviour. As a result, this model has served as the basis for a wide range of research in several areas of marketing 
(Kitchen et al., 2014), and it has been extended by different academics, in response to the requirements of the new contexts. For example, Cho (1999) was a pioneer in extending the model to research on digital contexts (MELM) to understand how people process advertising on the Internet. Similarly, Hershberger (2003) replicated the model in computer-mediated environments, developing the eELM. Afterwards, it has also been applied to study other aspects in the digital environment, such as consumer perceptions of online shopping environments (Demangeot and Broderick, 2007) or consumer adoption of e-commerce recommenders (Martínez-López et al., 2015).

The ELM revolves around the notion of elaboration. Elaboration is defined as "the extent to which a person carefully thinks about an argument” (Petty and Cacioppo, 1986, p. 128). Specifically, the degree of elaboration is established in a continuum that extends from two extremes: from not thinking about the relevant information present in the message to a total elaboration or complete processing of all the arguments (Petty and Cacioppo, 1986). Two routes represent these extremes: the central and peripheral routes. Moreover, the degree of elaboration likelihood, and thus the election of the central or peripheral route, is determined by individuals' motivation and ability (Petty et al., 1983).

The central route occurs when the motivation and ability to examine the relevant arguments related to the matter are high. In this case, the information processing (or elaboration) demands a high cognitive effort and the individual focuses the attention on conscious and rational arguments (e.g. rational arguments about the brand). The peripheral route is followed when motivation, ability, or both are relatively low. In this sense, the information processing through the peripheral route entails less cognitive effort and the individual focuses on more superficial arguments (Petty et al., 1983).

Prior empirical work that uses the ELM to understand consumer behaviour in the digital retail context has proposed different aspects as central and peripheral cues. For example, Gregory et al. (2013) focused on the website and proposed the content - the information - and the website design -usability and aesthetics- as the arguments to process the information through the central and the peripheral routes, respectively. More recently, Gu et al. (2017) in the mobile context, proposed privacy aspects, such as the perceived permission sensitivity and permission justification, as central cues; and the perceived app popularity as a peripheral cue. In addition, Cyr et al. (2018) described the argument quality of the website as the central route, and the website design elements, such as aesthetics and navigation, as the peripheral route.

In this work, the ELM is reformulated including variables that allow us to understand the suitability of this model in an evolved context. Moreover, we contribute to the knowledge of consumers' attitudes after the information processing in the digital context. Specifically, the central route, where the elaboration likelihood is high, is formed by strong arguments (interactivity and security and privacy) that represent the consumer's evaluation of the utilitarian experience. On the other hand, the elaboration through the peripheral route includes low arguments (visual appeal and enjoyment) that represent the evaluation of the hedonic experience. As the ELM proposes, the elaboration likelihood depends on consumers' motivation and ability. In this case, emotions are novelty posited as the motivation to process the information, considering prior studies that have emphasized the importance of emotions in the elaboration processing (Petty et al., 2003). Besides, the omni-tendency is proposed as the F1 ability to process, which will act as a moderating variable (see Figure 1).

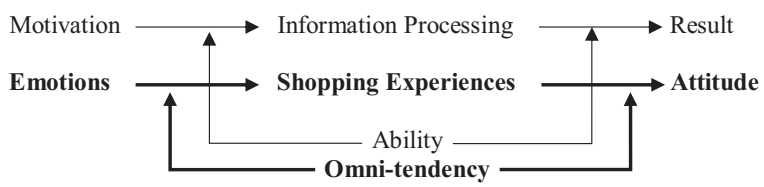

Figure 1. Application of ELM to digital contexts

Omnichannel in digital information processing

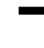


The ELM was proposed as a theory for understanding attitude formation and change (Petty et al., 1983). Attitude, defined as "an individual's positive or negative feeling about performing the target behaviour" (Fishbein and Ajzen, 1975, p. 288), has been extensively studied in different contexts. Within the digital shopping context, it has been broadly confirmed as a crucial determinant of consumer behaviour (Xu-Priour et al., 2017). For example, attitude was established as one of the main factors that determines consumer trust (Oliveira et al., 2017) and digital purchase intentions (Moon et al., 2017). Focusing on ELM, attitude is proposed as a function of likelihood to elaborate the message. In this sense, when the elaboration is high, information processing will occur via the central route; conversely, when the elaboration is low, information processing will be done through the peripheral route. Therefore, in the central route, the attitudes will be determined by the conscious and rational processing of the information. In the peripheral route, attitudes will appear determined fundamentally by the superficial signals present in the context. In sum, attitude induced via the central route involves considerably more cognitive work than attitude induced under the peripheral route (Petty and Cacioppo, 1986).

Therefore, applying ELM, consumer evaluation of the shopping experience is posited as the information processing (Demangeot and Broderick, 2007). Specifically, this paper focuses on the two dimensions of consumer evaluations, utilitarian and hedonic (Blázquez, 2014; Mano and Oliver, 1993; San José-Cabezudo et al., 2008). These dimensions refer to the result of the consumer shopping experience evaluation. Precisely, adapting from Babin and Darden (1995), the utilitarian experience refers to overall consumer assessment of website functional benefits, such as interactivity and security and privacy, and the hedonic experience comprises consumer evaluation of those website aspects that make it a more attractive place to spend time, such as visual appeal and enjoyment.

As has been mentioned, the central route processes arguments related to more relevant information and it entails more effort investment in the evaluation process. In this case, the utilitarian view reflects the consumer purchase in an efficient and timely manner to achieve consumer goals and can be viewed as reflecting a more task-oriented, cognitive and rational result of shopping (Babin et al., 1994; Holbrook and Hirschman, 1982). The peripheral route processes less relevant information and it requires less effort investment. In contrast to the central route - where relevant cues are crucial -, in the peripheral route, superficial cues play a more important role in attitude formation (Schulze et al., 2014). Consistently, the hedonic point of view refers to the shopping experience itself, regardless of shopping goals (Babin and Darden, 1995). It is related more to fun and playfulness than to task achievement (Babin et al., 1994; Holbrook and Hirschman, 1982).

Thus, giving that processing a message through the central route demands a high cognitive effort (Aghakhani et al., 2018), utilitarian experience, characterized by strong arguments, represents the information processing via the central route. Conversely, hedonic experience, related more to superficial aspects, depicts the information processing through the peripheral route where the elaboration entails less cognitive effort (Aghakhani et al., 2018).

Considering these variables, prior literature has argued that both utilitarian and hedonic experiences guide consumer shopping (Babin et al., 1994). Previous literature has shown that both utilitarian and hedonic components are vital to brand (Voss et al., 2003) and digital shopping attitude formation (Moon et al., 2017), and the key to increasing the repurchase intention (Chiu et al., 2014). Similarly, these two motivations were confirmed critical for attitude towards the website and, subsequently, attitude towards the brand and the intention to buy the brand (San José-Cabezudo et al., 2008). In addition, in the multichannel context, both utilitarian and hedonic beliefs were stated as determinants of consumers' attitude toward channel migration (Pookulangara et al., 2011). Besides, these two aspects are also 
essential in the omnichannel context. Specifically, the hedonic and utilitarian shopping values perceived by the consumer in the different channels contribute to the overall omnichannel value (Huré et al., 2017).

Consequently,

H1. Consumers' attitude towards the digital store will be formed by (a) the central route (utilitarian experience) and (b) the peripheral route (hedonic experience).
Omnichannel in digital information processing

\subsection{Emotions, the motivation to process in digital contexts}

As the ELM suggests, individuals' motivation is one of the factors that determines the degree of elaboration likelihood (Petty et al., 1983). Therefore, this motivation to process the information will influence the route they focus on in the process. Motivation refers to a goaldirected arousal (Park and Mittal, 1985), where the goal is delimited by the processing of information (MacInnis et al., 1991). Specifically, MacInnis et al. (1991, p. 34) define motivation as "consumers' desire or readiness to process brand information". They argue that motivation is the arousal that guides the consumer to process external stimuli. Following this definition, in the current paper, emotions are considered the motivation that leads consumers to process the information, because emotions are "mental states of readiness" (Bagozzi et al., 1999, p. 185). Although prior ELM literature has considered different individuals internal aspects, such as the need for cognition or involvement (San-Martín et al., 2011; Tam and Ho, 2005) as the motivation to process the information, to expand the ELM approach from an affective point of view (Burke and Edell, 1989), emotions are included in our ELM model. This was suggested by Petty and Briñol (2011), who stated that emotions can work as motivational forces and make positive thoughts more accessible.

Emotions during consumption are defined as episodes of intense feelings associated with a specific referent (such as people, objects or events) and triggering specific behavioural responses (Cohen and Areni, 1991). In this sense, there is a consensus in marketing literature that emotions explain human decision-making and behaviours (e.g. Holbrook and Hirschman, 1982). Moreover, the biological theory of emotions posits that emotional states precede cognitive states during the process of appraisal. In this sense, emotional reactions emerge more quickly than cognitive assessments and emotional processing can occur without conscious awareness (Zajonc, 1980, 1984; Zajonc and Markus, 1984). Some authors have suggested that emotional states can be processed and activated subconsciously (Bagozzi et al., 1999). Consequently, consumers' emotional responses have been confirmed as a strong antecedent of consumer evaluation and judgement of different experiences, which in turn influence their attitudes towards the brand (Kempf, 1999). In addition, the literature has demonstrated how emotions impact on other consumer evaluations such as brand extension evaluations (Barone et al., 2000) or perceived overall image (Prayag et al., 2015). Focusing on the digital context, emotions can also have a positive impact on consumer experiences. For example, Mazaheri et al. (2012) revealed that emotions during online shopping positively influence different consumer website evaluations, ultimately improving consumers' attitudes towards site and service. More recently, Richard and Chebat (2016) showed that the emotions that emerge during online shopping influence the website characteristics evaluated by the consumer, which in turn has a positive impact on their online attitudes. Consequently,

H2. The (a) utilitarian (central route) and (b) hedonic (peripheral route) information processing will be positively influenced by emotions emerging during the digital shopping process. 
Following the ELM, ability is another factor that determines the elaboration likelihood, and therefore the route that consumers use (Petty et al., 1983). Ability refers to "consumers'skills or proficiencies in interpreting brand information" (MacInnis et al., 1991, p. 34). In this sense, the frequency of use is an indicator of the level of experience (Alba and Hutchinson, 1987) and when consumers see themselves more experienced they develop greater ability to process information (MacInnis et al., 1991).

For this specific case, it is known that omni-consumers make more frequent purchases (Kumar and Venkatesan, 2005). In addition, it has been confirmed that previous experience with omnichannel services offers consumers the ability to evaluate better the technology they use and increases the probability to perform conscious processing (Shen et al., 2018). Moreover, in the multichannel context, Blázquez (2014) found that the level of experience makes a difference in consumers' perceptions about the online channel, in the case of fashion shopping. Accordingly, a greater experience as omni-consumer will imply more ability in the digital store. As a result, frequent omni-consumers will focus their attention on the rational and measurable features during the shopping process (central cues), while infrequent omniconsumers (those who have less experience) will focus on aspects related with the way in which the contents are presented (peripheral cues).

Regarding the utilitarian and hedonic evaluations, in the multichannel context, Choi and Park (2006) found that single-channel consumers tend to be more apathetic than multichannel consumers who are more utilitarian shoppers. In addition, Kwon and Jain (2009) supported that both hedonic and utilitarian motivations are critical in the multichannel context. These authors also found that utilitarian attributes are more important for high-level multichannel shoppers than for non-multichannel shoppers. In the online context, Overby and Lee (2006) established that when consumers develop their preference towards a retailer, the utilitarian value is more important for frequent shoppers and the hedonic value is more important for infrequent shoppers.

Summarizing, consumers with more omni-tendency (who have more ability) will probably use the central route (i.e. utilitarian experience) rather than the peripheral route (i.e. hedonic experience), and vice versa, in the attitude generation. Consequently,

H3. The effect of emotions on (a) utilitarian (central route) and (b) hedonic experiences (peripheral route) will be moderated by the consumers' omni-tendency.

H4. The effect of (a) utilitarian (central route) and (b) hedonic experiences (peripheral route) on attitude towards the digital store will be moderated by the consumers' omni-tendency.

Figure 2 summarises the proposed research model.

Figure 2.

Proposed

research model

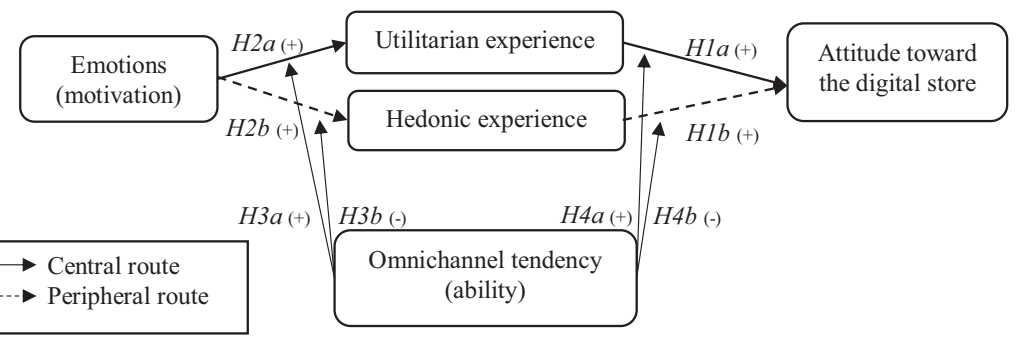

OIR — OIR-08-2019-0272_proof — 2 October 2020 — 5:30 am 


\section{Research methodology}

\subsection{Procedure}

The data was collected from digital shoppers of a Spanish corporate clothing group. After refining the questionnaire with the members of the marketing and digital commerce department, an email with the link to the online questionnaire was sent to 1,649 consumers. Only clients who had already purchased in the online or mobile store were selected. To encourage them to take part, a $5 €$ discount coupon for their next purchase was given after completing the questionnaire. The coupon could only be entered once from any given IP address, in this way we confirmed that respondents only completed the questionnaire once. The email was opened by $655(40.63 \%)$ and 284 answered the questionnaire.

To complete the questionnaire, the respondents were first requested to think about their last digital shopping experience with the firm. Then questions about the utilitarian and hedonic experience of shopping in accordance with this last digital shopping experience and their attitude were included. After, questions about omnichannel consumer traits were then asked, considering specifically the general omni-tendency.

Table 1 describes the sample characteristics. These aspects are similar to those of average Spanish digital shoppers of clothing. Specifically, $74 \%$ of digital shoppers in this sector are women, between 36 and 50 years old (52\%) (Stylight, 2016). In this case, the percentage of women is higher because the corporate clothing group selected focuses on women's clothes. Moreover, the moment of the day chosen for purchasing clothes is the afternoon (Stylight, 2016), which is in line with the sample of this research.

\begin{tabular}{|c|c|c|c|}
\hline Demographic variable & Size & $\%$ & \\
\hline \multicolumn{4}{|l|}{ Gender } \\
\hline Females & 280 & 98.6 & \\
\hline Males & 4 & 1.4 & \\
\hline \multicolumn{4}{|l|}{ Age } \\
\hline$<18$ & 0 & 0 & \\
\hline $18-35$ & 65 & 33.3 & \\
\hline $36-50$ & 207 & 64.2 & \\
\hline$>50$ & 12 & 2.4 & \\
\hline \multicolumn{4}{|l|}{ Occupation } \\
\hline Unemployed & 15 & 5.3 & \\
\hline Student & 6 & 2.1 & \\
\hline Retired & 4 & 1.4 & \\
\hline Employed & 243 & 85.6 & \\
\hline Homeworker & 16 & 5.6 & \\
\hline \multicolumn{4}{|c|}{ Moment chosen for digital purchases of clothes } \\
\hline Morning & 87 & 30.6 & \\
\hline Midday & 16 & 5.6 & \\
\hline Afternoon & 93 & 32.7 & \\
\hline Night & 88 & 31 & \\
\hline \multicolumn{4}{|c|}{ Experience as digital shopper } \\
\hline$<6$ months & 44 & 15.5 & \\
\hline 6-12 months & 20 & 7 & \\
\hline $1-3$ years & 77 & 27.1 & Table 1. \\
\hline$>3$ years & 143 & 50.4 & Sample characteristics \\
\hline
\end{tabular}

Omnichannel in digital information processing 
The clothing industry was selected to carry out this study for several reasons. First, on the basis that omnichannel management has not developed equally in all industries, clothing has been one of the sectors to show good results in omnichannel implementation (Gao and Yang, 2016). Second, clothes are in the top ten categories in which digital devices have more influence when consumers shop in stores (Deloitte, 2016). In fact, in Spain, one out of five online clothing purchases includes an offline search and one out of three offline purchases is preceded by an online search (Google, 2017). Finally, it has been one of the main topics in marketing literature in different contexts, including the omnichannel context (Blázquez, 2014).

\subsection{Measurement development}

The questionnaire for this study was developed from reliable and valid scales taken and adapted to this study context from previous literature. The variables were measured through 5 -point Likert scales, ranging from strongly disagree (1) to strongly agree (5). Firstly, the questionnaire comprised emotional and cognitive variables. To measure emotions, a semantic differential scale was used with five items taken from Li et al. (2012). Utilitarian and hedonic experiences were measured taking second-order constructs. Utilitarian experience was composed of two functional attributes of the digital store (Babin and Darden, 1995): interactivity and security and privacy. Interactivity is defined as the degree to which two or more communicating parties can synchronize and act on each other through the communicative medium with their messages (Liu and Shrum, 2002). This variable was measured with five items adapted from Ballantine and Fortin (2009). Security and privacy refer to the technical safeguards to ensure that legal requirements are met and best practices adhered to when dealing with personal details (Casaló et al., 2007). It comprises six items from the work of San-Martín and Camarero (2008). Hedonic experience comprised two characteristics related to the fun and pleasure of the digital store (Babin and Darden, 1995): visual appeal and enjoyment. Visual appeal is the balance, emotional appeal or aesthetics of a website that is expressed through colours, shapes, language, music or animation (Cyr et al., 2006). This variable was measured using three items adapted from Mathwick et al. (2001). Enjoyment is defined as the consumers' direct experience of immediate pleasure and joy from using the website (Lu and Su, 2009). It was measured with three items taken from Lu and $\mathrm{Su}$ (2009). Consumer attitude towards the digital store was measured with three items adapted from Lee (2005). The constructs and items are shown in Tables 2 and 3.

The second part of the questionnaire comprised questions aimed at gauging consumers' omnichannel personal trait. In this case, the omni-tendency identifies the consumers' own perceptions about their omnichannel frequency, in other words how they see themselves as omni-consumers. Concretely the variable represents the consumer perception about their own omnichannel ability. Consequently, to measure this trait, we used consumer tendency to engage in their general clothing decision-making processes in an omnichannel manner, that is combining physical and digital channels (Lazaris and Vrechopoulos, 2014) and concretely moving between the online $(\mathrm{PC})$, mobile devices and physical store (Piotrowicz and Cuthbertson, 2014). This work considers the two basic stages of the decision-making process: information search and purchase. These two stages are the ones where the combination of different channels is more frequent (De Keyser et al., 2015) and they are considered to be suitably separated for analysis (Chiou et al., 2017). In addition, we considered in the omnichannel process the combination of the traditional channel (offline) and digital channels in this case taking into account the online and mobile channels - (Rodríguez-Torrico et al., 2017). Individuals were thus asked how often - from (1) not often to (5) very often (Elhai et al., 2016) - they engaged in four omnichannel processes in their clothes shopping decisions: (1) searching offline and purchasing online, (2) searching online and purchasing offline, (3) 


\begin{tabular}{|c|c|c|c|c|c|}
\hline Variable & Dimensions & Items & Loadings & $t$-value & Umnichanne \\
\hline \multirow[t]{6}{*}{$\begin{array}{l}\text { Hedonic } \\
\text { experience }\end{array}$} & \multirow{3}{*}{$\begin{array}{l}\text { Visual Appeal }(\alpha=0.967 \\
\mathrm{CR}=0.979, \mathrm{AVE}=0.938) \\
\text { (Mathwick } \text { et al., } 2001)\end{array}$} & $\begin{array}{l}\text { The way the firm displays its } \\
\text { products was attractive }\end{array}$ & 0.961 & 107.620 & information \\
\hline & & $\begin{array}{l}\text { Digital store } X \text { was aesthetically } \\
\text { appealing }\end{array}$ & 0.979 & 242.217 & processin \\
\hline & & $\begin{array}{l}\text { I liked the way the digital store } \\
\text { looked }\end{array}$ & 0.966 & 122.583 & \\
\hline & \multirow{3}{*}{$\begin{array}{l}\text { Enjoyment }(\alpha=0.936, \\
\mathrm{CR}=0.959, \mathrm{AVE}=0.886)(\mathrm{Lu} \\
\text { and } \mathrm{Su}, 2009)\end{array}$} & $\begin{array}{l}\text { Surfing digital store } X \text { was } \\
\text { enjoyable }\end{array}$ & 0.943 & 93.721 & \\
\hline & & $\begin{array}{l}\text { Overall, when I have accessed } \\
\text { digital store } X, \text { I have felt pleased }\end{array}$ & 0.964 & 137.138 & \\
\hline & & $\begin{array}{l}\text { Overall, I believe that visiting } \\
\text { digital store } X \text { was fun }\end{array}$ & 0.917 & 64.037 & \\
\hline \multirow[t]{11}{*}{$\begin{array}{l}\text { Utilitarian } \\
\text { experience }\end{array}$} & \multirow{6}{*}{$\begin{array}{l}\text { Security and privacy } \\
(\alpha=0.956, \mathrm{CR}=0.965, \\
\mathrm{AVE}=0.820) \\
\text { (San-Martín and Camarero, } \\
\text { 2008) }\end{array}$} & $\begin{array}{l}\text { Digital store } X \text { was safe and had a } \\
\text { privacy policy regarding consumer } \\
\text { and privacy information }\end{array}$ & 0.881 & 47.828 & \\
\hline & & $\begin{array}{l}\text { Digital store } X \text { informed the } \\
\text { consumer about security and } \\
\text { privacy policies }\end{array}$ & 0.857 & 37.884 & \\
\hline & & $\begin{array}{l}\text { I felt safe when sending personal } \\
\text { information through digital store } X\end{array}$ & 0.932 & 79.214 & \\
\hline & & $\begin{array}{l}\text { I think my rights regarding my } \\
\text { personal details were respected in } \\
\text { digital store } X\end{array}$ & 0.939 & 75.270 & \\
\hline & & $\begin{array}{l}\text { I think digital store } X \text { had } \\
\text { mechanisms that ensure the safe } \\
\text { transmission of its users' } \\
\text { information }\end{array}$ & 0.928 & 75.135 & \\
\hline & & $\begin{array}{l}\text { I felt safe sending confidential } \\
\text { information (credit card number, } \\
\text { bank account information) when I } \\
\text { paid in digital store } X\end{array}$ & 0.894 & 43.980 & \\
\hline & \multirow[t]{5}{*}{$\begin{array}{l}\text { Interactivity }(\alpha=0.915, \\
\mathrm{CR}=0.936, \mathrm{AVE}=0.746) \\
\text { (Ballantine and Fortin, 2009) }\end{array}$} & $\begin{array}{l}\text { I think digital store } X \text { was able to } \\
\text { respond to my specific requests for } \\
\text { information }\end{array}$ & 0.866 & 45.945 & \\
\hline & & $\begin{array}{l}\text { Digital store } X \text { allowed me to } \\
\text { communicate easily with the } \\
\text { company, whenever I had a specific } \\
\text { question }\end{array}$ & 0.831 & 29.500 & \\
\hline & & $\begin{array}{l}\text { Digital store } X \text { let me access other } \\
\text { consumers' opinions easily about } \\
\text { the products featured }\end{array}$ & 0.833 & 28.752 & \\
\hline & & $\begin{array}{l}\text { I think digital store } X \text { really gave me } \\
\text { some control over the content I } \\
\text { wanted to see }\end{array}$ & 0.915 & 80.726 & \\
\hline & & $\begin{array}{l}\text { Overall, I think digital store } X \text { was } \\
\text { highly interactive }\end{array}$ & 0.871 & 45.435 & $\begin{array}{r}\text { First-order } \\
\text { measurement model }\end{array}$ \\
\hline
\end{tabular}

searching offline and mobile purchasing and (4) mobile searching and purchasing offline. Finally, omni-tendency was determined by calculating the arithmetical average of the values of these four different omnichannel processes.

In order to verify that respondents answered consistently regarding their omni-tendency, a control variable was included in the questionnaire. This variable, called Channels Used for Decision-Making (CUDM), represents the number of channels that the respondents normally 
OIR

\begin{tabular}{llccccc}
\hline & Items of the reflective & & & & & \\
Variable & dimensions & Loadings & $t$-value & $\alpha$ & CR & AVE \\
\hline Emotions (Li et al., 2012) & "During your last purchase occasion, you felt. . ” & & & \\
& Happy-Unhappy & 0.809 & 22.103 & 0.904 & 0.926 & 0.717 \\
& Pleased-Annoyed & 0.849 & 25.666 & & & \\
& Free-Restricted & 0.897 & 63.836 & & & \\
& Wide awake-Sleepy & 0.919 & 72.446 & & & \\
Excited-Calm & 0.750 & 18.806 & & & \\
Attitude towards the & Using digital store $X$ for & 0.947 & 97.417 & 0.953 & 0.970 & 0.915 \\
digital store (Lee, 2005) & purchasing is a good idea & & & & & \\
& Using digital store $X$ for & 0.969 & 158.740 & & & \\
& purchasing is a wise idea & & & & & \\
& Using digital store $X$ for & 0.953 & 111.032 & & & \\
& purchasing is an appealing idea & & & & &
\end{tabular}

Table 3.

Second-order measurement model

\begin{tabular}{llcrcr}
\hline Variable & Formative dimensions & Weights & $t$-value & VIF & IT \\
\hline Utilitarian experience & Interactivity & 0.856 & 12.816 & 2.208 & 0.453 \\
& Security and privacy & 0.184 & 2.348 & 2.208 & 0.453 \\
Hedonic experience & Visual Appeal & 0.631 & 7.381 & 1.972 & 0.507 \\
& Enjoyment & 0.450 & 5.266 & 1.972 & 0.507 \\
& & & &
\end{tabular}

use to carry out the different stages of the decision-making process - searching, evaluating alternatives, purchasing, paying, returning and giving feedback. As the omni-tendency is a subjective self-assessment, this control variable allows us to limit any inconsistency in the responses.

\section{Results}

This study used Partial Least Squares Structural Equation Modelling (PLS-SEM) to analyse data. PLS-SEM is a multivariate analysis approach that allows path models to be estimated with latent variables. This approach is robust for small samples and complex models (Hair et al., 2018).

Specifically, to measure and estimate the structural model, the statistical software SmartPLS Version 3.2.6 and bootstrap resampling (5,000 resamples) were used. Multigroup analysis (MGA) was also performed to test the moderating role of omni-tendency. To this end, median split categorised participants into two groups, frequent and infrequent omnichannel consumers. Median split has generally been used in marketing research as a statistical approach for assessing moderating effects based on multigroup analysis (Kim et al., 2017). Additionally, we performed a $t$-test of mean difference which showed that the ad hoc created groups are indeed significantly different $\left(M_{\text {freq-omni }}=3.001(n=131) ;\right.$ vs $\mathrm{M}_{\text {infreq-omni }}=1.668$ $(n=153) ; F=565.961, p<0.001)$. The mean (SD) of the whole sample for omnichannel frequency is $2.284(0.815)$. As pointed out previously, some omnichannel processes are still infrequent and in their infancy (Rodríguez-Torrico et al., 2017).

\subsection{Measurement model}

In order to avoid common method bias we follow Podsakoff et al. (2003). First, we refined the questionnaire with three members of the corporate clothing group who are experts in marketing and digital commerce. Second, the respondents were informed that all the information gathered will be used exclusively for academic purposes and that their anonymity will be ensured. Third, the independent and depended variables were placed separately in the questionnaire. Finally, the full collinearity VIFs were calculated 
(Attitude $=4.3$, Visual appeal $=3.4$, Enjoyment $=3.1$, Security and Privacy $=2.8$, Interactivity $=3.9$ and Emotions $=1.27$ ). In all the cases the collinearity is discarded because the VIFs are below the threshold of 5 (Hair et al., 2006). Therefore, it can be considered that there is not any problem of common method bias.

Utilitarian and hedonic experiences are considered as reflective-formative second-order constructs created by two dimensions each; namely interactivity and security and privacy, and enjoyment and aesthetics, respectively. As the second-order constructs are reflectiveformative and explained by emotions, the two-stage approach needs to be used to measure the model (Hair et al., 2018).

First, the validity and reliability of the first-order level scales were assessed (Hair et al., 2011) (Table 2). The reliability and internal consistency of the scales were confirmed: Cronbach $\alpha$ was above 0.7 and composite reliability (CR) was above 0.6 (Bagozzi and Yi, 1988). In addition, the average variance extracted (AVE) values were above 0.5 in all cases, confirming convergent validity (Bagozzi and Yi, 1988). The direct relations between the dimensions and their indicators showed in all cases significant loading values $(t>1.96$, at a $95 \%$ confidence level), supporting the construct validity. Therefore, the validated first-order constructs (hedonic experience and utilitarian experience) could then be incorporated into the second-order measurement model (Hair et al., 2018).

The results of the second-order measurement model are presented in Table 3 . As can be seen, all loading and weight coefficients show significant values at a confidence level of $95 \%$ $(t>1.96)$ for both formative and reflective latent variables. As regards reflective latent variables, Cronbach $\alpha$, CR and AVE values confirmed the scales' reliability and validity, with values above $0.7,0.6$ and 0.5 , respectively. For the formative constructs, multicollinearity was ruled out, with VIF values below 5 and IT above 0.10 .

Discriminant validity was confirmed by calculating whether the square root of the AVE from each reflective construct was in every case greater than the correlations of the other

T4 reflective constructs (Table 4) using the Fornell-Larcker Criterion (Fornell and Larcker, 1981). In addition, the Heterotrait-Monotrait Ratio (HTMT) displays a suitable score (0.466) between emotions and attitude (Henseler et al., 2015), being under 0.9.

\subsection{Structural model analysis}

Once the measurement model was validated, we tested $\mathrm{H} 1$ and $\mathrm{H} 2$ by estimating the global model. Previously, we analysed $R^{2}$ to confirm the explanatory power of the research. Results show that $R^{2}$ is satisfactory because it exceeded 0.1 for attitude towards the digital store (0.760) and for utilitarian (0.165) and hedonic (0.150) experience (Falk and Miller, 1992).

As shown in Table 5, all paths were significant at 0.001 levels. Therefore, all the direct proposed hypotheses were confirmed. Specifically, utilitarian and hedonic experiences explain attitude towards the digital store, supporting H1a and H1b. In addition, emotions positively influence both utilitarian and hedonic experiences, thus also confirming H2a and $\mathrm{H} 2 \mathrm{~b}$.

\begin{tabular}{lcccc}
\hline & 1 & 2 & 3 & 4 \\
\hline 1. EMO & 0.847 & & & \\
2. ATT & 0.435 & 0.956 & - & - \\
3. UE & 0.401 & 0.814 & 0.821
\end{tabular}

Note(s): EMO, emotions; ATT, attitude towards the digital store; UE, utilitarian experience; HE, hedonic experience. Diagonal entries are square root of AVE (in italics); others are correlation coefficients
Omnichannel in digital information processing

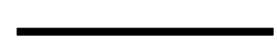




\section{OIR}

\subsection{Multi-group analysis}

After analysing the structural model, we tested the moderating role of the omni-tendency. For this purpose, PLS-based MGA was applied to examine the differences between frequent and infrequent omnichannel consumers. PLS-MGA does not require any distributional assumptions. In this test, the two groups are compared subject to separate bootstrap analyses, and the bootstrap outcomes serve as a basis for the hypothesis tests of group differences (Henseler et al., 2009). However, before proceeding to MGA-PLS analysis, the measurement invariance was established. The measurement invariance of composite models (MICOM) approach was run following Henseler et al. (2016). On the one hand, the configural invariance is confirmed because, in both groups, constructs are equally parameterized and estimated. On the other hand, the compositional invariance is established because none of the $c$ values are significantly different from one; and also the equality of the composites' mean values and logarithms of variances is proved (Table 6) (Hair et al., 2018; Henseler et al., 2016). Consequently, the full measurement invariance is supported.

MGA results are presented in Table 7. Before examining group differences, we can observe the estimated model for both subsamples. As can be seen, for both frequent and infrequent omnichannels, all paths present significant coefficients.

Furthermore, focusing on the differences between groups, the results reveal several significant differences between frequent and infrequent omnichannels. Specifically, and in contrast to our proposal, emotions have a weaker influence on utilitarian experience for frequent omnichannels than for infrequent ones, thus, H3a cannot be confirmed. On the other hand, emotions present a stronger effect on hedonic experience for those consumers who have a higher omni-tendency, confirming H3b. In addition, attitude towards the digital store is more weakly affected by hedonic experience for frequent omnichannels than for infrequent omnichannels; and the relationship between utilitarian experience and attitude shows stronger value for frequent omnichannels than for the infrequent ones, supporting $\mathrm{H} 4$ at a 0.10 level of significance ( $90 \%$ of confidence).

\section{Discussion}

This paper has allowed us to understand that the way the omnichannel consumer reacts in the digital store can be influenced by his/her omni-tendency. First, our findings confirm that consumers' attitude towards the digital store is determined by the evaluation that they make

\begin{tabular}{lcc}
\hline Hypotheses & Path coefficient & Test results \\
\hline H1a. Utilitarian experience $\rightarrow$ Attitude & $0.370^{* * * *}$ & Supported \\
H1b. Hedonic experience $\rightarrow$ Attitude & $0.542^{* * * *}$ & Supported \\
H2a. Emotions $\rightarrow$ Utilitarian experience & $0.401^{* * *}$ & Supported \\
H2b. Emotions $\rightarrow$ Hedonic experience & $0.391^{* * *}$ & Supported \\
Note(s): $* * * *<<0.001, * * p<0.01, * p<0.05, n$. s.: not significant & \\
\hline
\end{tabular}

Table 5.

Structural model results

\begin{tabular}{lccc}
\hline Composite & $\begin{array}{c}c \text { value (permutation } \\
p \text {-value) }\end{array}$ & $\begin{array}{c}\text { Mean values (permutation } \\
p \text {-value) }\end{array}$ & $\begin{array}{c}\text { Logarithms of variance } \\
\text { (permutation } p \text {-value) }\end{array}$ \\
\hline Attitude & $1.000(0.494)$ & $-0.087(0.465)$ & $0.281(0.185)$ \\
Emotions & $0.998(0.457)$ & $-0.017(0.882)$ & $-0.077(0.740)$ \\
Hedonic & $0.989(0.292)$ & $-0.164(0.169)$ & $0.100(0.642)$ \\
Utilitarian & $0.982(0.088)$ & $-0.108(0.365)$ & $0.050(0.797)$ \\
\hline
\end{tabular}




\begin{tabular}{|c|c|c|c|c|c|}
\hline Hypotheses & $\begin{array}{l}\text { Infrequent omni- } \\
\text { consumers } \\
\text { Path coef }\end{array}$ & $\begin{array}{l}\text { Frequent omni- } \\
\text { consumers } \\
\text { Path coef }\end{array}$ & $\begin{array}{l}\text { Path coef. } \\
\text { Differences }\end{array}$ & $\begin{array}{c}p \text {-value } \\
\text { MGA }\end{array}$ & $\begin{array}{r}\text { Umnichannel } \\
\text { in digital } \\
\text { information }\end{array}$ \\
\hline H3a. EMO $\rightarrow$ UE & $0.510^{* * *}$ & $0.296^{* * * *}$ & $0.214^{*}$ & 0.029 & 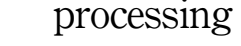 \\
\hline H3b. EMO $\rightarrow \mathrm{HE}$ & $0.555^{* * * *}$ & $0.221^{*}$ & $0.334^{* * * *}$ & 0.001 & \\
\hline H4a. UE $\rightarrow$ ATT & $0.297 * * *$ & $0.461 * * *$ & $0.164^{\dagger}$ & 0.933 & \\
\hline H4b. HE $\rightarrow$ ATT & $0.608 * * * *$ & $0.467 * * *$ & $0.140^{+}$ & 0.100 & \\
\hline CUDM $\rightarrow$ UE & $0.019^{\text {n.s }}$ & $-0.062^{\text {n.s }}$ & $0.080^{+}$ & 0.059 & \\
\hline $\mathrm{CUDM} \rightarrow \mathrm{HE}$ & $0.052^{\text {n.s }}$ & $-0.092^{\text {n.s }}$ & $0.144^{\dagger}$ & 0.076 & \\
\hline $\mathrm{CUDM} \rightarrow \mathrm{ATT}$ & $0.005^{\mathrm{n} . \mathrm{s}}$ & $-0.095^{\mathrm{n} . \mathrm{s}}$ & $0.099^{\text {n.s }}$ & 0.167 & \\
\hline
\end{tabular}

Note(s): EMO, emotions; UE, utilitarian experience; HE, hedonic experience; ATT, attitude towards the digital store; CUDM, channels used for decision-making; $* * * p<0.001$, $* * p<0.01, * p<0.05$, $t p<0.1$, n.s.: not significant

Table 7.

PLS-MGA results

from both their utilitarian and hedonic experience. This result is consistent with previous research that has proved the influence of both utilitarian and hedonic aspects of the website on users' attitude (San José-Cabezudo et al., 2008). In addition, the results show that both utilitarian and hedonic experiences are significantly influenced by the emotions that arise during the digital shopping. These findings are in line with previous studies. For example, Richard and Chebat (2016) found that as the emotions are more positive, users make a more effective evaluation of the website content which, in turn, positively impacts the website attitude. Similarly, Mazaheri et al. (2012) found that emotions positively affect consumer site evaluation - represented by effectiveness, informativeness and entertainment - and this evaluation improves consumer attitudes towards the digital store in the case of services. Focusing on clothing, our findings extend the results of Kim and Lennon (2010), who studied the positive influence of emotions on consumer evaluation about the amount of information provided on the website. The results of this paper also confirm the influence of both central and peripheral routes in the information processing and attitude formation (San JoséCabezudo et al., 2009).

Second, the emotions sparked during digital shopping enhance the evaluation of this shopping experience more when a consumer presents less omni-tendency. In this sense, we posited that the relationship between emotions and utilitarian experience (central route) would be stronger for frequent omni-consumers because they present higher ability. Contrary to our proposal, the findings point that utilitarian experience is influenced by emotions significantly more for infrequent than for frequent omni-consumers. The character of emotions, which is affective in nature, can explain this result. In this sense, the affect is proposed as a possible responsible for the direction that information processing will take along the elaboration likelihood continuum (Petty et al., 2001). Additionally, some literature has considered that affect is associated solely with the peripheral route (Miller et al., 2009). Therefore, emotions can be used more as motivation for those consumers who have less ability, because emotions do not entail a high cognitive effort and are related to the peripheral route.

Finally, attitude towards the digital store is determined by the experiences for both frequent and infrequent omni-consumers. However, there are differences between omniconsumers in terms of their experiences. According to our proposal, the cues that offer consumers pleasure and fun are more important for infrequent omni-consumers than for the frequent ones. Moreover, and in line with our expectations, frequent omni-consumers show a greater impact than infrequent omnichannels of utilitarian experience on attitude towards the digital store. These findings support the propositions of Petty et al. (1983), who proposed the elaboration as a continuum. When the ability to process the information increases (in this 
case, higher omni-tendency), the users follow the central route to process the information. On the contrary, if the ability is low (in this case, lower omni-tendency), the individuals use the peripheral route. Furthermore, these results reinforce the suitability of the ELM to enrich the understanding of consumer behaviour in the omnichannel context and support prior research. Specifically, these results corroborate the statements of Shen et al. (2018), who mentioned that when consumers' ability increases, the likelihood to perform conscious processing is higher. Moreover, this paper also extends the results of prior literature (Blázquez, 2014) by confirming that depending on the omnichannel tendency the evaluations and attitudes are different. Besides, this work expands, to the omni-consumers case, the results of Overby and Lee (2006), who found that as the shopping frequency increases the utilitarian values are more important than the hedonic ones.

\section{Implications}

\subsection{Theoretical implications}

This paper makes several contributions to the academic field mainly in the omnichannel context but also to digital marketing literature. First, this research has led the study of omniconsumer tendency, confirming its effect on the digital channel. As mentioned before, omniconsumers are a new type of consumers who are gaining importance in both the academic and managerial fields because of their widespread implementation of omnichannel behaviours (Ailawadi and Farris, 2017). With this in mind, the present paper proposes treating this new omni-tendency as a consumer trait, considering that there are consumers who can be regarded as more omnichannel than others (Rodríguez-Torrico et al., 2017). This work provides evidence that omni-consumers are different regarding the way they react in the digital channel, confirming the assumptions of previous literature (Dholakia et al., 2010) and advancing in the omnichannel context knowledge.

Second, the current research applies the ELM in the digital context to understand the particular case of omni-consumers. In line with prior literature (Cho, 1999; Hershberger, 2003), this model, that has been unexplored in omnichannel literature, has been adapted to this context and confirms its suitability for studying omni-consumer attitude. As a result, this paper contributes to digital information processing theory and supports the importance of adapting the theories to respond the current necessities of each context. Since evolved contexts require adapting the constructs to explain the new phenomena, in this case, the use of this approach has provided a deeper understanding of the specific omnichannel phenomenon. Concretely, omnichannel behaviours are the result of consumer evolution and affects how they use all the channels (Dholakia et al., 2010). As a result, it is necessary to understand the impact of these omnichannel behaviours in the way consumers process the information. Follow the ELM, this study proposes the omni-tendency as the consumer's ability to process the information. This new construct confirms its influence on consumer elaboration and attitude formation in the digital channel.

Finally, this paper contributes theoretically to the ELM literature by extending the constructs that explain the elaboration likelihood. In addition to omni-tendency as ability, this work proposes the inclusion of emotions as the motivation to process. Motivation in the ELM has been traditionally considered as a cognitive variable, related to personal relevance, need for cognition or personal responsibility (Petty and Cacioppo, 1986), among others. In this sense, some authors have underlined the need for replicating the model in a new form, adapting it to the dramatic changes arisen in consumer behaviour (Kitchen et al., 2014). Following this recommendation, in this concrete case, we try to expand the approach from an affective point of view (Babin et al., 1994). In this sense, although the literature stated that in the absence of other motivational forces, emotions can be key in the information processing (Petty and Briñol, 2011), this variable has been scarcely proposed as a motivation to elaborate. Consequently, this paper provides evidence about the appropriateness of including other 
variables in traditional models to explain current contexts. Similarly, these results are in line with the assumptions of the biological theory of emotions (Zajonc, 1984). In this case, emotions and omni-tendency enrich marketing literature and contribute to consumer behaviour knowledge and ELM extension.

\subsection{Managerial implications}

Based on our findings and considering how consumers' omni-tendency impacts on their digital shopping process, the results of this study offer some implications and recommendations for practitioners vis-à-vis managing the omnichannel context. First, retailers should bear consumers' emotions in mind since these prove crucial in the subsequent evaluation of their experience and attitude generation. As a result, firms should construct an environmental atmosphere in all the channels, since prior literature pointed out that ambient (e.g. colour or background conditions), design (e.g. presentation or organization) and social (e.g. vendors attention or interaction) elements are crucial for developing emotions (Chang et al., 2011; Lee and Jeong, 2012). In this case, some keys to create this environmental atmosphere that ensure omnichannel consumers' emotions might involve adaptations in channel management, for example, by integrating the digital channel according to the remaining touchpoints (Xu-Priour et al., 2017) to create a seamless ambient of the firm and offering the same design and services. Some ways to achieve this might be addressed through atmospheric cues, clear information or good service, both in physical and digital channels. Therefore, if consumers switch between digital and physical channels and find the same image and conditions in each, their emotions may be positive and in turn, their evaluations will improve. One example of this seamless action is Inditex [3], which allows consumers to carry out their decision-making process wherever they want, interchanging channels and devices according to their needs and wishes, providing freedom in channel selection for each of the decision-making phases. In addition, both utilitarian and hedonic characteristics are important for improving attitude towards the digital store. In this line, omnichannel retailers should provide clear, faithful and seamless information about shopping conditions, security and privacy terms and the possibility of being attended by vendors (digital and physically) at all the touchpoints. In addition, designing an entertaining and attractive website is crucial to enhance the shopping experience.

Second, although for both frequent and infrequent omnichannels emotions and experiences are crucial in the attitude formation, firms should not forget that consumers' omni-tendency makes them different. Retailers must have in mind that for infrequent omniconsumers the emotions and hedonic experience are more important than for frequent omniconsumers because the ability of the latter can be lower than the former. Therefore, in order to make infrequent omnichannels to use more the central route of processing - which is considered to have more persistent results and to be an indicator of future behaviour - firms can focus on increasing their ability within this omnichannel context. To this end, they can encourage the use of multiple channels - which will increase consumers' experience-offering the possibility of doing other shopping activities in another channel and explaining them how. For example, when consumers are searching for information, firms can alert them that they can go to the store to try the product and buy it there; after purchasing in the digital store, they can be informed that they can pick up the product at the physical store. In this way, firms will also be able to improve the frequent omni-consumers' ability, which will maintain them using the central route.

Finally, knowing that consumer segmentation is a key issue when designing effective omnichannel strategies (Neslin et al., 2006) and that omni-tendency influences the consumers reactions, firms should consider the omnichannel trait as a possible criterion when segmenting consumers. To do that, firms should first track consumers' journeys between channels and identify those who are omni-consumers and their paths. Through good channel integration,
Omnichannel in digital information processing

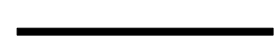

OIR — OIR-08-2019-0272_proof — 2 October 2020 — 5:30 am 
firms can follow the consumer's journey, offering exclusive consumer identification. It allows consumers to switch freely between touchpoints without the need to identify themselves in each channel and firms can record consumers' movements and follow their paths. After that, firms must design specific strategies for this segment, based on offering an omnichannel shopping experience. This can be accomplished by showing consumers good channel integration, providing them with consistency, synchronization and freedom between channels. Firms should inform them through alerts or messages such as: "you can finish your purchase in the store, order the product in the app and pick it up offline...".

\subsection{Limitations and future research}

This research has also some limitations that can be addressed in further studies. First, this work only considers the impact of omni-tendency on consumers' digital experiences. This limitation points the way towards new research which should consider how omnichannel consumers perceive their offline experiences and should test the differences between frequent and infrequent omnichannel consumers' experiences using this channel. Apart from the offline channel, a future comparative research study might explore consumer omni-tendency at different touchpoints, such as social media, wearables or personal assistants.

Second, we measure the omni-tendency trait as a frequency with which consumers engage in omnichannel processes, including the search-purchase sequence. In this sense, it could be interesting for future studies to develop a scale to measure omni-tendency as an individual trait and include additional aspects such as consumer innovativeness towards new touchpoints, and also consider the post-purchase stage of the decision-making process, among others.

Finally, our sample comprised digital shoppers from a Spanish corporate clothing group, which might limit the generalizability of our results. Moreover, although our sample is similar to the profile of digital shoppers of clothes, it presents an imbalanced ratio between males and females, which may affect the generalization of the results to clothing male or unisex companies. Consequently, future research can replicate this work using gender-balanced samples and other product categories.

\section{Notes}

1. For ease of explanation we use the term "omnichannel" throughout this paper, acknowledging that the literature has focused on multi, cross and omnichannel contexts and that the concepts have different nuances.

2. The term digital refers to both online and mobile channels.

3. Inditex is one of the world's largest fashion retailers, with eight brands (Zara, Pull\&Bear, Massimo Dutti, Bershka, Stradivarius, Oysho, Zara Home and Uterqüe) and 7,385 stores in 94 markets around the world. https://www.inditex.com/.

\section{References}

Aghakhani, N., Karimi, J. and Salehan, M. (2018), "A unified model for the adoption of electronic word of mouth on social network sites: facebook as the exemplar", International Journal of Electronic Commerce, Vol. 22 No. 2, pp. 202-231.

Ailawadi, K.L. and Farris, P.W. (2017), "Managing multi- and Omni-channel distribution: metrics and research directions", Journal of Retailing, Vol. 93 No. 1, pp. 120-135.

Alba, J.W. and Hutchinson, J.W. (1987), "Dimensions of consumer expertise", Journal of Consumer Research, Vol. 13 No. 4, pp. 411-454.

Babin, B.J. and Darden, W.R. (1995), “Consumer self-regulation in a retail environment”, Journal of Retailing, Vol. 71 No. 1, pp. 47-70. 
Babin, B.J., Darden, W.R. and Griffin, M. (1994), "Work and/or fun: measuring hedonic and utilitarian shopping value", Journal of Consumer Research, Vol. 20 No. 4, pp. 644-656.

Bagozzi, R.P. and Yi, Y. (1988), "On the evaluation of structural equation models", Journal of the Academy of Marketing Science, Vol. 16 No. 1, pp. 74-94.

Bagozzi, R.P., Gopinath, M. and Nyer, P.U. (1999), "The role of emotions in marketing”, Journal of the Academy of Marketing Science, Vol. 27 No. 2, pp. 184-206.

Ballantine, P.W. and Fortin, D.R. (2009), "The effects of interactivity and product information on consumers' emotional responses to an online retail setting", International Journal of Internet Marketing and Advertising, Vol. 5 No. 4, pp. 260-271.

Barone, M.J., Miniard, P.W. and Romeo, J.B. (2000), "The influence of positive mood on brand extension evaluations", Journal of Consumer Research, Vol. 26 No. 4, pp. 386-400.

Blázquez, M. (2014), "Fashion shopping in multichannel retail: the role of technology in enhancing the customer experience", International Journal of Electronic Commerce, Vol. 18 No. 4, pp. 97-116.

Burke, M.C. and Edell, J.A. (1989), "The impact of feelings on ad-based affect and cognition”, Journal of Marketing Research, Vol. 26 No. 1, pp. 69-83.

Casaló, L.V., Flavián, C. and Guinalíu, M. (2007), "The role of security, privacy, usability and reputation in the development of online banking”, Online Information Review, Vol. 31 No. 5, pp. 583-603.

Chang, H.J., Eckman, M. and Yan, R.N. (2011), "Application of the Stimulus-Organism-Response model to the retail environment: the role of hedonic motivation in impulse buying behavior", The International Review of Retail, Distribution and Consumer Research, Vol. 21 No. 3, pp. 233-249.

Chiou, J.S., Chou, S.Y. and Shen, G.C.C. (2017), "Consumer choice of multichannel shopping: the effects of relationship investment and online store preference", Internet Research, Vol. 27 No. 1, pp. 2-20.

Chiu, C.M., Wang, E.T., Fang, Y.H. and Huang, H.Y. (2014), “Understanding customers' repeat purchase intentions in $\mathrm{B} 2 \mathrm{C}$ e-commerce: the roles of utilitarian value, hedonic value and perceived risk", Information Systems Journal, Vol. 24 No. 1, pp. 85-114.

Cho, C.H. (1999), "How advertising works on the WWW: modified elaboration likelihood model", Journal of Current Issues and Research in Advertising, Vol. 21 No. 1, pp. 34-50.

Choi, J. and Park, J. (2006), "Multichannel retailing in Korea: effects of shopping orientations and information seeking patterns on channel choice behavior", International Journal of Retail and Distribution Management, Vol. 34 No. 8, pp. 577-596.

Cohen, J.B. and Areni, C.S. (1991), "Affect and consumer behavior", in Robertson, T.S. and Kassarjian, H.H. (Eds), Handbook of Consumer Behavior, Prentice-Hall, Englewood Cliffs, pp. 188-240.

Cyr, D., Head, M. and Ivanov, A. (2006), "Design aesthetics leading to m-loyalty in mobile commerce", Information and Management, Vol. 43 No. 8, pp. 950-963.

Cyr, D., Head, M., Lim, E. and Stibe, A. (2018), "Using the elaboration likelihood model to examine online persuasion through website design", Information and Management, Vol. 55 No. 7, pp. 807-821.

Dabholkar, P.A. and Bagozzi, R.P. (2002), "An attitudinal model of technology-based self-service: moderating effects of consumer traits and situational factors", Journal of the Academy of Marketing Science, Vol. 30 No. 3, pp. 184-201.

De Keyser, A., Schepers, J. and Konuş, U. (2015), "Multichannel customer segmentation: does the aftersales channel matter? A replication and extension", International Journal of Research in Marketing, Vol. 32 No. 4, pp. 453-456.

Deloitte (2016), "Navigating the new digital divide: a global summary of findings from nine countries on digital influence in retail", available at: http://www2.deloitte.com/global/en/pages/consumerbusiness/articles/gx-global-digital-divide-retail.html (accesed 12 April 2019).

Demangeot, C. and Broderick, A.J. (2007), "Conceptualising consumer behaviour in online shopping environments", International Journal of Retail and Distribution Management, Vol. 35 No. 11, pp. 878-894.

Omnichannel in digital information processing

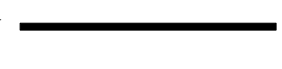


Dholakia, U.M., Kahn, B.E., Reeves, R., Rindfleisch, A., Stewart, D. and Taylor, E. (2010), “Consumer behavior in a multichannel, multimedia retailing environment", Journal of Interactive Marketing, Vol. 24 No. 2, pp. 86-95.

Elhai, J.D., Levine, J.C., Dvorak, R.D. and Hall, B.J. (2016), "Fear of missing out, need for touch, anxiety and depression are related to problematic smartphone use", Computers in Human Behavior, Vol. 63, pp. 509-516.

Falk, R.F. and Miller, N.B. (1992), A Primer for Soft Modeling, University of Akron Press, Akron.

Fishbein, M. and Ajzen, I. (1975), Belief, Attitude, Intention and Behavior: An Introduction to Theory and Research, Addison-Wesley, Reading.

Fornell, C. and Larcker, D.F. (1981), "Evaluating structural equation models with unobservable variables and measurement error", Journal of Marketing Research, Vol. 18 No. 3, pp. 39-50.

Gao, R. and Yang, Y.X. (2016), “Consumers' decision: fashion Omni-channel retailing”, Journal of Information Hiding and Multimedia Signal Processing, Vol. 7 No. 2, pp. 325-342.

Google (2017), “Cómo se busca y se compra moda en España?", available at: https://www. thinkwithgoogle.com/intl/es-es/insights/busca-y-compra-moda-espana/ (accesed 5 April 2019).

Gregory, C.K., Meade, A.W. and Thompson, L.F. (2013), "Understanding internet recruitment via signaling theory and the elaboration likelihood model", Computers in Human Behavior, Vol. 29 No. 5, pp. 1949-1959.

Gu, J., Xu, Y.C., Xu, H., Zhang, C. and Ling, H. (2017), "Privacy concerns for mobile app download: an elaboration likelihood model perspective", Decision Support Systems, Vol. 94, pp. 19-28.

Hair, J.F., Black, W.C., Babin, B.J., Anderson, R.E. and Tatham, R.L. (2006), Multivariate Data Analysis, Pearson Prentice Hall, Upper Saddle River, NJ.

Hair, J.F., Ringle, C. and Sarstedt, M. (2011), "PLS-SEM: indeed a silver bullet", Journal of Marketing Theory and Practice, Vol. 19 No. 2, pp. 139-152.

Hair, J.F., Sarstedt, M., Ringle, C. and Gudergan, S.P. (2018), Advanced Issues in Partial Least Squares Structural Equation Modeling, Sage Publications, Thousand Oaks.

Henseler, J., Ringle, C.M. and Sinkovics, R.R. (2009), "The use of partial least squares path modeling in international marketing", in Sinkovics, R.R. and Ghauri, P.N. (Eds), Advances in International Marketing, Emerald Group Publishing Limited, Bingley, pp. 277-319.

Henseler, J., Ringle, C.M. and Sarstedt, M. (2015), “A new criterion for assessing discriminant validity in variance-based structural equation modeling", Journal of the Academy of Marketing Science, Vol. 43 No. 1, pp. 115-135.

Henseler, J., Ringle, C.M. and Sarstedt, M. (2016), "Testing measurement invariance of composites using partial least squares", International Marketing Review, Vol. 33 No. 3, pp. 405-431.

Hershberger, E.K. (2003), eELM: A Replication and Enhancement of the Elaboration Likelihood Model for Computer-Mediated Environments, Georgia State University, Atlanta.

Holbrook, M.B. and Hirschman, E.C. (1982), "The experiential aspects of consumption: consumer fantasies, feelings and fun”, Journal of Consumer Research, Vol. 9 No. 2, pp. 132-141.

Huré, E., Picot-Coupey, K. and Ackermann, C.L. (2017), "Understanding omni-channel shopping value: a mixed-method study", Journal of Retailing and Consumer Services, Vol. 39, pp. 314-330.

Kempf, D.S. (1999), "Attitude formation from product trial: distinct roles of cognition and affect for hedonic and functional products", Psychology and Marketing, Vol. 16 No. 1, pp. 35-50.

Kim, H. and Lennon, S.J. (2010), "E-atmosphere, emotional, cognitive, and behavioral responses", Journal of Fashion Marketing and Management, Vol. 14 No. 3, pp. 412-428.

Kim, K., Kim, J. and Reid, L.N. (2017), "Experiencing motivational conflict on social media in a crisis situation: the case of the Chick-fil-A same-sex marriage controversy", Computers in Human Behavior, Vol. 71, pp. 32-41. 
Kitchen, P.J., Kerr, G., Schultz, D.E., McColl, R. and Pals, H. (2014), “The elaboration likelihood model: review, critique and research agenda", European Journal of Marketing, Vol. 48 Nos 11/12, pp. 2033-2050.

Kumar, V. and Venkatesan, R. (2005), "Who are the multichannel shoppers and how do they perform?: correlates of multichannel shopping behavior", Journal of Interactive Marketing, Vol. 19 No. 2, pp. 44-62.

Kwon, K.-N. and Jain, D. (2009), "Multichannel shopping through nontraditional retail formats: varietyseeking behavior with hedonic and utilitarian motivations", Journal of Marketing Channels, Vol. 16 No. 2, pp. 149-168.

Lazaris, C. and Vrechopoulos, A. (2014), "From multichannel to 'Omnichannel' retailing: review of the literature and calls for research", Paper Presented at 2nd International Conference on Contemporary Marketing Issues (ICCMI).

Lee, T. (2005), "The impact of perceptions of interactivity on customer trust and transaction intentions in mobile commerce", Journal of Electronic Commerce Research, Vol. 6 No. 3, pp. 165-181.

Lee, S. and Jeong, M. (2012), "Effects of e-servicescape on consumers' flow experiences", Journal of Hospitality and Tourism Technology, Vol. 3 No. 1, pp. 47-59.

Li, M., Dong, Z.Y. and Chen, X. (2012), "Factors influencing consumption experience of mobile commerce: a study from experiential view”, Internet Research, Vol. 22 No. 2, pp. 120-141.

Liu, Y. and Shrum, L. (2002), "What is interactivity and is it always such a good thing? Implications of definition, person, and situation for the influence of interactivity on advertising effectiveness", Journal of Advertising, Vol. 31 No. 4, pp. 53-64.

Lu, H.P. and Su, P.Y.J. (2009), "Factors affecting purchase intention on mobile shopping web sites", Internet Research, Vol. 19 No. 4, pp. 442-458.

MacInnis, D.J., Moorman, C. and Jaworski, B.J. (1991), "Enhancing and measuring consumers' motivation, opportunity, and ability to process brand information from ads", Journal of Marketing, Vol. 55 No. 4, pp. 32-53.

Mano, H. and Oliver, R.L. (1993), "Assessing the dimensionality and structure of the consumption experience: evaluation, feeling, and satisfaction”, Journal of Consumer Research, Vol. 20 No. 3, pp. 451-466.

Martínez-López, F.J., Esteban-Millat, I., Cabal, C.C. and Gengler, C. (2015), "Psychological factors explaining consumer adoption of an e-vendor's recommender", Industrial Management and Data Systems, Vol. 115 No. 2, pp. 284-310.

Mathwick, C., Malhotra, N. and Rigdon, E. (2001), "Experiential value: conceptualization, measurement and application in the catalog and Internet shopping environment", Journal of Retailing, Vol. 77 No. 1, pp. 39-56.

Mazaheri, E., Richard, M.O. and Laroche, M. (2012), "The role of emotions in online consumer behavior: a comparison of search, experience, and credence services", Journal of Services Marketing, Vol. 26 No. 7, pp. 535-550.

Miller, C.E., Reardon, J., Salciuviene, L., Auruskeviciene, V., Lee, K. and Miller, K.E. (2009), "Need for cognition as a moderator of affective and cognitive elements in online attitude toward the brand formation”, Journal of Business \& Economics Research (JBER), Vol. 7 No. 12, pp. 65-72.

Moon, M.A., Khalid, M.J., Awan, H.M., Attiq, S., Rasool, H. and Kiran, M. (2017), "Consumer's perceptions of websités utilitarian and hedonic attributes and online purchase intentions: a cognitive-affective attitude approach", Spanish Journal of Marketing - ESIC, Vol. 21 No. 2, pp. $73-88$.

Neslin, S.A., Grewal, D., Leghorn, R., Shankar, V., Teerling, M.L., Thomas, J.S. and Verhoef, P.C. (2006), "Challenges and opportunities in multichannel customer management", Journal of Service Research, Vol. 9 No. 2, pp. 95-112.

Oliveira, T., Alhinho, M., Rita, P. and Dhillon, G. (2017), "Modelling and testing consumer trust dimensions in e-commerce", Computers in Human Behavior, Vol. 71, pp. 153-164.
Omnichannel in digital information processing

$+$ 
Overby, J.W. and Lee, E.J. (2006), "The effects of utilitarian and hedonic online shopping value on consumer preference and intentions", Journal of Business Research, Vol. 59 Nos 10-11, pp. 1160-1166.

Park, C. and Mittal, B. (1985), "A theory of involvement in consumer: behavior: problems and issues", in Sheth, J.N. (Ed.), Research in Consumer Behavior, JAI Press, Greenwich, pp. 201-231.

Petty, R.E. and Briñol, P. (2011), "The elaboration likelihood model", in Berkowitz, L. (Ed.), Handbook of Theories of Social Psychology, Springer, New York, NY, pp. 224-245.

Petty, R.E. and Cacioppo, J.T. (1979), "Issue involvement can increase or decrease persuasion by enhancing message-relevant cognitive responses", Journal of Personality and Social Psychology, Vol. 37 No. 10, p. 1915.

Petty, R.E. and Cacioppo, J.T. (1986), "The elaboration likelihood model of persuasion", Communication and Persuasion, Springer Series in Social Psychology, New York, NY, pp. 1-24.

Petty, R.E., Cacioppo, J.T. and Schumann, D. (1983), "Central and peripheral routes to advertising effectiveness: the moderating role of involvement", Journal of Consumer Research, Vol. 10 No. 2 , pp. 135-146.

Petty, R.E., DeSteno, D. and Rucker, D.D. (2001), “The role of affect in attitude change”, in Forgas, J.P. (Ed.), Handbook of Affect and Social Cognition, Lawrence Erlbaum Associates Publishers, pp. 212-233.

Petty, R.E., Fabrigar, L.R. and Wegener, D.T. (2003), "Emotional factors in attitudes and persuasion", in Davidson, R.J., Scherer, K.R. and Goldsmith, H.H. (Eds), Handbook of Affective Sciences, Oxford University Press, p. 772.

Piotrowicz, W. and Cuthbertson, R. (2014), "Introduction to the special issue information technology in retail: toward omnichannel retailing", International Journal of Electronic Commerce, Vol. 18 No. 4 , pp. 5-16.

Podsakoff, P.M., MacKenzie, S.B., Lee, J.-Y. and Podsakoff, N.P. (2003), "Common method biases in behavioral research: a critical review of the literature and recommended remedies", Journal of Applied Psychology, Vol. 88 No. 5, pp. 879-903.

Pookulangara, S., Hawley, J. and Xiao, G. (2011), "Explaining multi-channel consumer's channelmigration intention using theory of reasoned action", International Journal of Retail and Distribution Management, Vol. 39 No. 3, pp. 183-202.

Prayag, G., Hosany, S., Muskat, B. and Del Chiappa, G. (2015), "Understanding the relationships between tourists' emotional experiences, perceived Overall image, satisfaction, and intention to recommend", Journal of Travel Research, Vol. 56 No. 1, pp. 41-54.

Richard, M.O. and Chebat, J.C. (2016), "Modeling online consumer behavior: preeminence of emotions and moderating influences of need for cognition and optimal stimulation level", Journal of Business Research, Vol. 69 No. 2, pp. 541-553.

Rodríguez-Torrico, P., San-Jose Cabezudo, R. and San-Martín, S. (2017), "Tell me what they are like and I will tell you where they buy. An analysis of omnichannel consumer behavior", Computers in Human Behavior, Vol. 68, pp. 465-471.

San José-Cabezudo, R., Gutiérrez-Cillán, J. and Gutiérrez-Arranz, A.M. (2008), "The moderating role of user motivation in Internet access and individuals' responses to a Website", Internet Research, Vol. 18 No. 4, pp. 393-404.

San José-Cabezudo, R., Gutiérrez-Arranz, A.M. and Gutiérrez-Cillán, J. (2009), "The combined influence of central and peripheral routes in the online persuasion process", CyberPsychology and Behavior, Vol. 12 No. 3, pp. 299-308.

San-Martín, S. and Camarero, C. (2008), "Consume trust to a web site. Moderating effect of attitudes towards online shopping", CyberPsychology and Behavior, Vol. 11, pp. 549-554.

San-Martín, S., Camarero, C. and San José, R. (2011), "Does involvement matter in online shopping satisfaction and trust?", Psychology and Marketing, Vol. 28 No. 2, pp. 145-167. 
Schulze, C., Schöler, L. and Skiera, B. (2014), "Not all fun and games: viral marketing for utilitarian products", Journal of Marketing, Vol. 78 No. 1, pp. 1-19.

Shen, X.L., Li, Y.J., Sun, Y. and Wang, N. (2018), "Channel integration quality, perceived fluency and omnichannel service usage: the moderating roles of internal and external usage experience", Decision Support Systems, Vol. 109, pp. 61-73.

Sopadjieva, E., Dholakia, U.M. and Benjamin, B. (2017), "A study of 46,000 shoppers shows that Omnichannel retailing works", Harvard Business Review, Vol. 3, pp. 1-2.

Stylight (2016), "El Mapa del Shopping Online ¿Quién compra moda online? (The online shopping map. Who buy fashion online? for a tentative translation)", available at: https://love.stylight.es/ work/el-mapa-del-shopping-online/ (accesed 26 November 2019).

Tam, K.Y. and Ho, S.Y. (2005), "Web personalization as a persuasion strategy: an elaboration likelihood model perspective", Information Systems Research, Vol. 16 No. 3, pp. 271-291.

Trampe, D., Stapel, D.A., Siero, F.W. and Mulder, H. (2010), "Beauty as a tool: the effect of model attractiveness, product relevance, and elaboration likelihood on advertising effectiveness", Psychology and Marketing, Vol. 27 No. 12, pp. 1101-1121.

Verhoef, P.C., Kannan, P. and Inman, J.J. (2015), "From multi-channel retailing to omni-channel retailing: introduction to the special issue on multi-channel retailing", Journal of Retailing, Vol. 91 No. 2, pp. 174-181.

Voss, K.E., Spangenberg, E.R. and Grohmann, B. (2003), "Measuring the hedonic and utilitarian dimensions of consumer attitude", Journal of Marketing Research, Vol. 40 No. 3, pp. 310-320.

Xu-Priour, D.L., Cliquet, G. and Palmer, A. (2017), "The influence of buyers' time orientation on Online shopping behavior: a typology", International Journal of Electronic Commerce, Vol. 21 No. 3, pp. 299-333.

Yang, K. (2012), "Consumer technology traits in determining mobile shopping adoption: an application of the extended theory of planned behavior", Journal of Retailing and Consumer Services, Vol. 19 No. 5, pp. 484-491.

Zajonc, R.B. (1980), "Feeling and thinking: preferences need no inferences", American Psychologist, Vol. 35 No. 2, p. 151.

Zajonc, R.B. (1984), “On the primacy of affect”, American Psychologist, Vol. 39 No. 2, pp. 117-123.

Zajonc, R.B. and Markus, H. (1984), "Affect and cognition: the hard interface, Emotions, Cognition, AQ: $7 \quad$ And Behavior, pp. 73-102.

\section{Corresponding author}

AQ:3 Paula Rodríguez-Torrico can be contacted at: prtorrico@ubu.es
Omnichannel in digital information processing

$+$ 